\title{
Weight Loss and Nutrient Dynamics during Leaf Litter Decomposition of Quercus mongolica in Mt. Worak National Park
}

\author{
Mun, Hyeong-Tae \\ Dept. of Biology, Kongju National University, Kongiu 314-701, Korea
}

\begin{abstract}
Weight loss and nutrient dynamics of Quercus mongolica leaf litter during decomposition were investigated from December 2005 through August 2008 in Mt. Worak National Park as a part of National Long-Term Ecological Research Program in Korea. The decay constant $(k)$ of $Q$. mongolica litter was 0.26 . After 33 months decomposition, remaining weight of $Q$. mongolica litter was $49.3 \pm 4.4 \%$. Initial $C / N$ and $C / P$ ratios of $Q$. mongolica litter were 43.3 and 2,032 , respectively. C/N ratio in decomposing litter decreased rapidly from the beginning to nine months decomposition, and then showed more or less constant. C/P ratio increased to 2,407 after three months decomposition, and then decreased steadily thereafter. $N$ and $P$ concentration increased significantly during decomposition. $\mathrm{N}$ immobilization occurred from the beginning through 18 months decomposition, and mineralization occurred afterwards in decomposing litter. $\mathrm{P}$ immobilized significantly from fifteen months during decomposition. $K$ concentration decreased rapidly from the beginning to six months decomposition. However it showed an increasing pattern during later stage of decomposition. Remaining $K$ decreased rapidly during early stage of decomposition. There was no net $\mathrm{K}$ immobilization. Ca concentration increased from the beginning to twelve months decomposition, and then decreased rapidly till twenty one months elapsed. However, it increased again thereafter. Ca mineralization occurred from fifteen months. $\mathrm{Mg}$ concentration increased during decomposition. There was no $\mathrm{Mg}$ immobilization during litter decomposition. After 33 months decomposition, remaining $\mathrm{N}, \mathrm{P}, \mathrm{K}, \mathrm{Ca}$ and $\mathrm{Mg}$ in $\mathrm{Q}$. mongolica litter were $79.2,110.9,36.2,52.7$ and $74.4 \%$, respectively.
\end{abstract}

Key words: C/N ratio, C/P ratio, Decay constant, Immobilization, Litter decomposition, Mineralization, Quercus mongolica

\section{INTRODUCTION}

Forest ecosystems are self-maintained through primary production and nutrient cycling. In most forests the major source of nutrient for tree growth is the process of litter decomposition. Therefore, the investigation of decomposition of litter is an important aspect of the analysis of ecosystem function (Wieder and Lang 1982). Decomposition of litter, which refers to the physical and chemical processes involved in reducing litter to simpler chemical constituents, is a primary mechanism and has received considerable attention for sustainable forest soil fertility (Alhamd et al. 2004, Xu et al. 2004). Decomposition of litter is mainly a biological process carried out by insects, worms, bacteria, and fungi both on the soil surface and in the soil (Satchell 1974). In general, climate rules decomposition on a regional scale whereas litter chemical composition dominates the process on a local scale. Meentemeyer (1978) and Berg et al. (1987) showed a large-scale effect which is affected by climate on decomposition rate of fresh plant litter.

The concentration of plant nutrient in litter material is important because of its influence both on the rate of decomposition of the litter and on the amounts of nutrient liberated during decomposition (Xu et al. 2004). Swift et al. (1979) proposed that litter quality is a major regulatory factor in litter decomposition. $\mathrm{CN}, \mathrm{C} / \mathrm{P}$ and lignin/ $\mathrm{N}$ ratios are frequently identified as the qualities most correlated with litter weight loss (Melillo et al. 1982, Taylor et al. 1989, Janssen 1996). High litter $N$ contents have generally been considered to increase decomposition rates, and a positive correlation between litter decay rates and $\mathrm{N}$ contents has been reported in a great number of studies (Enriquez et al. 1993, Xu et al. 2004). However, Berg et al. (1987) and Fog (1988) suggested that the role of $\mathrm{N}$ as a rate regulating factor in litter decomposition is not always clear, and seems to be linked to litter type and stage of decomposition.

As a part of National Long-Term Ecological Research Program in Korea, carbon and nutrient cycling in major plant communities, such as Pinus densiflora, Quercus variabilis and Q. mongolica, in Mt. Worak National Park in Chungbuk Province have begun since April 2005. As a part of nutrient cycling, we are conducting the study of litter production and decomposition in major plant communities. The objective of the present study was to quantify the

\footnotetext{
* Corresponding author; Phone: +82-41-850-8499, e-mail: htmun@kongjuac.kr
} 
weight loss, the changes of $\mathrm{C} / \mathrm{N}$ and $\mathrm{C} / \mathrm{P}$ ratios of substrate, and nutrient dynamics during litter decomposition of $Q$. mongolica in Mt. Worak National Park.

\section{MATERIALS AND METHODS}

\section{Study Area}

The Mt. Worak National Park is located between Mt. Sobaek and Mt. Songni (N 36 $47^{\prime} \sim 36^{\circ} 55^{\prime}$, E 128 $4^{\prime} \sim 128^{\circ} 12^{\prime}$ ), and stretches over both Gyeongsangbuk-do and Chungcheongbuk-do. The highest peak of the Mt. Worak National Park, Munsubong, is $1,162 \mathrm{~m}$ above sea level. $Q$. mongolica forest is located at $900 \mathrm{~m}$ above sea level at Medumak, south-west direction (N 36 $51^{\prime} 19^{\prime \prime}$, E $128^{\circ} 12^{\prime} 23^{\prime \prime}$ ). Tree density was 950 trees/ha and average DBH was $26.8 \pm 6.8 \mathrm{~cm}$ in 2005. In shrub layer, Lindera obtusiloba was dominated, and Fraxinus rhynchophylla and Lespedeza maximowiczii. were distributed with low density. In herb layer, Codonopsis lanceolata and Aster scaber were distributed with very low density. According to the Jecheon meteorological station, about $30 \mathrm{~km}$ distance from the study area, annual average temperature and precipitation for thirty years from 1976 through 2005 was $10.1^{\circ} \mathrm{C}$ and $1,349.8 \mathrm{~mm}$, respectively.

\section{Litterbag Preparation, Installing and Retrieval}

Freshly fallen oak leaves were collected in $Q$. mongolica forest on October 2005. They were oven dried at $80^{\circ} \mathrm{C}$ for $72 \mathrm{hrs}$. The litterbag technique was used, using litterbags ca. $20 \times 25 \mathrm{~cm}$, made with $2 \mathrm{~mm}$ mesh size polyethylene net. Approximately $5 \mathrm{~g}$ of litter was packed into each litterbag with an aluminum tag which gives the exact weight of litter enclosed. Litterbags were scattered on the forest floor on December 2005. They were fastened to the ground with string and nails.

Five litterbags were retrieved every three months from March 2006 through September 2008. Litterbags were cleaned free of soil, and oven dried at $80^{\circ} \mathrm{C}$. Weight loss and nutrient dynamics during litter decomposition were determined by measuring remaining weight and nutrient concentration of litter in the litterbags. Weight loss of litter was expressed as $\%$ of initial sample weight. The decay constant $(k)$ was calculated by Olson's $X_{t}=X_{0} e^{-k t}$, where $X_{\theta}$ is the initial weight of litter, $X_{t}$ is the remaining weight of litter after time $t, t$ is the time (in years), respectively (Olson 1963). Samples were ground with mixer for chemical analysis.

\section{Chemical Analysis}

Chemical analysis of litter were carried out with 3 replicates. $\mathrm{C} / \mathrm{N}$ ratios of initial and decomposing litter were analyzed with Elemental Analyzer (EA1112, Thermo Fisher Scientific Inc.). T-N and T-P were analyzed with Flow Injection Analyzer (Lachat: QuickChem 8000) after litter samples were digested on block digestor. K, $\mathrm{Ca}$ and $\mathrm{Mg}$ were determined with Atomic Absorption Spectrophotometer (Perkin-Elmer 3110) after wet digestion on block digestor (Allen et al. 1974). Remaining nutrient after a given month decomposition were calculated by the following formula:

$$
\text { Remaining nutrient }(\%)=\left(L_{t} C_{t} / L_{0} C_{0}\right) \times 100
$$

where $L_{t}$ is the dry weight of litter after time $t, L_{0}$ is the initial dry weight of litter, $C_{t}$ is the concentration of nutrient in litter after time $t$, and $C_{\theta}$ is the initial concentration of nutrient in litter (Alhamd et al. 2004).

\section{RESULTS AND DISCUSSION}

\section{Weight Loss}

Weight loss of $Q$. mongolica litter during decomposition continued steadily over 33 months (Fig. 1). After 12 months decomposition, litter lost $21.0 \pm 6.3 \%$ of the initial litter weight. Namgung et al. (2008) reported that $Q$. variabilis and Pinus densiflora litter lost $32.9 \%$ and $20.2 \%$, respectively, of the initial litter weight after 12 months decomposition. After 33 months decomposition, remaining weight of $Q$. mongolica litter was $49.4 \pm 4.4 \%$.

Weight loss in summer season (from 6 through 9 months, from 18 through 21 months and 30 through 33 months in Fig. 1) was greater than that in winter season. This may be due to the greater activities of decomposer in summer season and water soluble fractions in litter leached out more in wet summer season (Jensen 1974, Millar 1974, Swift et al. 1979). Namgung et al. (2008) reported that $Q$. variabilis and $P$. densiflora leaf litter lost $54.5 \%$

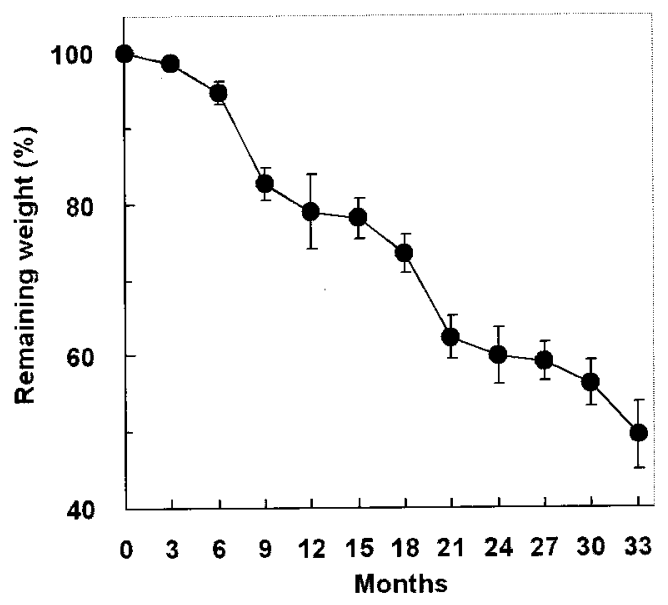

Fig. 1. Remaining weight (\%) in decomposing leaf litter of $Q$. mongolica in Mt. Worak National Park. Bars indicate SD. 
and $41.9 \%$, respectively, after 30 months decomposition. The decay constant $(k)$ of $Q$. mongolica litter was 0.257 . The decay constant $(k)$ of $Q$. mongolica litter was higher than that of $P$. densiflora leaf litter $(k=0.217)$, but lower than that of $Q$. variabilis leaf litter $(k=$ 0.314) (Namgung et al. 2008).

\section{$\mathrm{C} / \mathrm{N}$ and C/P Ratios of Decomposing Litter}

The $\mathrm{C}$ and $\mathrm{N}$ contents of litter are important as decomposer organisms which utilize carbon as a source of energy and nitrogen to grow and reproduce. Without sufficient nitrogen, there will be few microorganisms, and decomposition will be slow (Seereeram and Lavender 2003). Resource quality, such as $\mathrm{C} / \mathrm{N}, \mathrm{C} / \mathrm{P}$ and lignin $\mathrm{N}$ ratios, is recognized as one of the major regulatory factors in litter decomposition (Swift et al. 1979, Melillo et al. 1982, Taylor et al. 1989, Xu et al. 2004). High litter $\mathrm{N}$ contents have generally been considered to increase decomposition rates, and a positive correlation between litter decay rates and $\mathrm{N}$ contents has been reported in a great number of studies (Enriquez et al. 1993).

$\mathrm{C} / \mathrm{N}$ and $\mathrm{C} / \mathrm{P}$ ratios of decomposing $Q$. mongolica litter were depicted in Fig. 2. Initial $\mathrm{C} / \mathrm{N}$ and $\mathrm{C} / \mathrm{P}$ ratios of $Q$. mongolica litter was 43.3 and 2,032, respectively. Carbon \% of initial $Q$. mongolica litter was $45.7 \%$. However, $\mathrm{N}$ and $\mathrm{P}$ content of initial $Q$. mongolica litter was $1.06 \%$ and $0.023 \%$, respectively. $\mathrm{C} / \mathrm{N}$ ratio of decomposing litter decreased rapidly during the early stage of decomposition. After 9 months elapsed, $\mathrm{C} / \mathrm{N}$ ratio of decomposing litter was 23.2 . This is because $\mathrm{C}$ content of decomposing litter showed almost constant (38.9\% at 33 months elapsed), but $\mathrm{N}$ content increased during decomposition (Fig. 3A). C/P ratio of decomposing litter increased to 2,407 at 3 months elapsed, and then decreased steadily to 776 at 33 months elapsed (Fig. 2B).

$\mathrm{C} / \mathrm{N}$ ratios are often used as a measure to ensure that nitrogen is present in sufficient quantities for a proper nitrogen balance. Janssen (1996) suggested that mineralization of organic nitrogen requires microbial conversion of the organic material. Initial $\mathrm{CN}$ ratio of litter is higher than that of the microbes. The fraction of organic $\mathrm{N}$ that is mineralized is less than the fraction of organic $\mathrm{C}$ that is dissimilated. So, $\mathrm{C} / \mathrm{N}$ ratio of the remaining litter is decreasing during decomposition until it has the same value as that of the microbes. Janssen (1996) reported that more easily decomposable leaf species with low $\mathrm{CN}$ ratios harbored higher numbers of bacteria than did more resistant leaf species, especially in freshly fallen litter.

Gozs et al. (1973), Dziadowiec (1987) reported that C/P ratios of litter have a range of 200 to 480 . However, many other studies showed much higher initial C/P ratio (Berendse et al. 1989, Moro and Domingo 2000). Xu et al. (2004) reported that the initial C/P ratios in litter ranged from 896 to 2,467 .

\section{Nutrient Dynamics in the Decomposing Litter}

$N$ concentration in decomposing litter increased significantly during experimental period (Fig. 3A). Initial $\mathrm{N}$ concentration of $Q$. mongolica litter was $9.30 \mathrm{mg} / \mathrm{g}$, which was higher than that of $Q$ variabilis (Namgung et al. 2008). It increased to $15.48 \mathrm{mg} / \mathrm{g}$ at 27 months, and then decreased to $14.89 \mathrm{mg} / \mathrm{g}$ at 33 months elapsed The increase in $\mathrm{N}$ concentration in decomposing litter is a common observation (Berg and Staaf 1981, Melillo et al. 1982, Xu et al. 2004). Such an increase could be attributed to the addition of $N$ from exogenous sources into microbial biomass (Melillo et al. 1982, $\mathrm{Xu}$ et al. 2004). $\mathrm{N}$ immobilization occurred from the beginning through 18 months decomposition, and then $N$ mineralization occurred thereafter (Fig. 3B). After 33 months elapsed, $20.8 \%$ of initial $\mathrm{N}$ mass was released

Initial $\mathrm{P}$ concentration of $Q$. mongolica litter was $0.225 \mathrm{mg} / \mathrm{g}$, which was higher than that of $Q$. variabilis (Namgung et al. 2008). $\mathrm{P}$ concentration in decomposing litter also showed an increasing pattern during the experimental period (Fig. 3C). After 33 months elapsed, $P$ concentration of $Q$. mongolica litter was $0.504 \mathrm{mg} / \mathrm{g}$. Baker et al. (2001) reported that the behavior of $P$ during the decomposition process varies among species (Gosz et al. 1973, Schle-
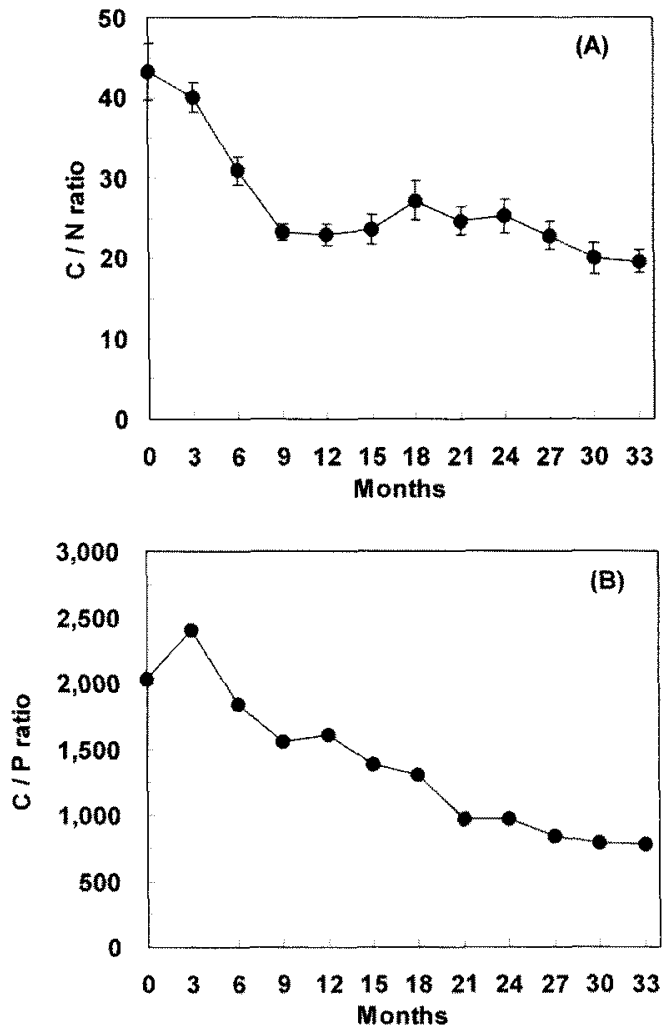

Fig. 2. Changes of $C N(A)$ and $C / P(B)$ ratio in decomposing leaf litter of $Q$. mongolica. in Mt. Worak National Park. Bars indicate SD. 
singer 1985). $\mathrm{P}$ in decomposing litter immobilized after 12 months decomposition (Fig. 3D). After 33 months elapsed, remaining $P$ was $111 \%$ of the initial $\mathrm{P}$ mass. The possible mechanisms for this immobilization may be retention in microbial biomass or translocation from fungal hyphae (Xu et al. 2004).

Initial $\mathrm{K}$ concentration of $Q$. mongolica litter was $2.36 \mathrm{mg} / \mathrm{g}$,
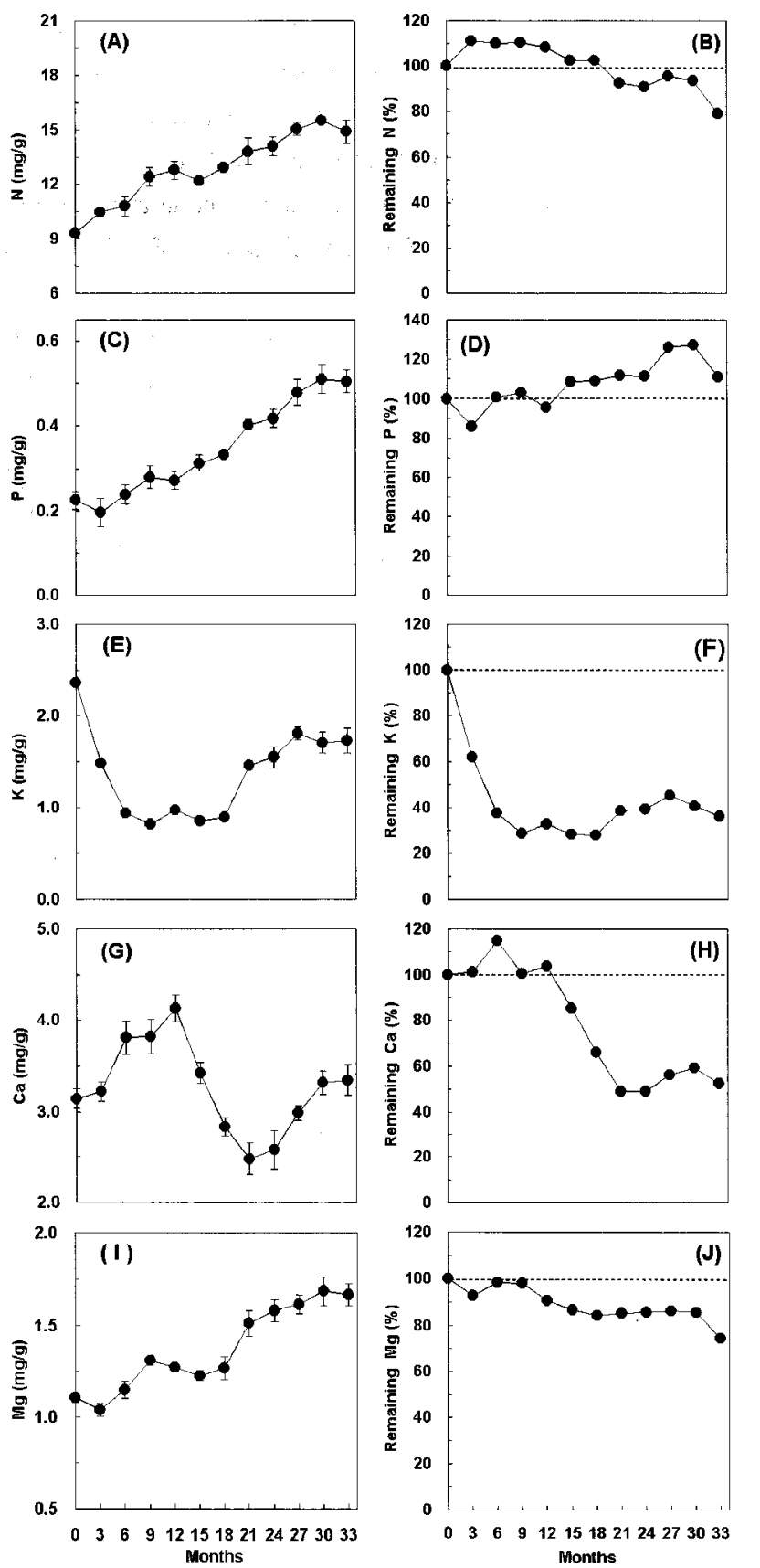

Fig. 3. Changes of $N(A), P(C), K(E), C a(G)$ and $M g(I)$ concentration, and \% remaining $\mathrm{N}(\mathrm{B}), \mathrm{P}(\mathrm{D}), \mathrm{K}(\mathrm{F}), \mathrm{Ca}(\mathrm{H})$ and $\mathrm{Mg}$ (J) in decomposing leaf litter of Q. mongolica in Mt. Worak National Park. Bars indicate SD. which was similar with that of $Q$. variabilis (Namgung et al. 2008). It decreased rapidly to $0.82 \mathrm{mg} / \mathrm{g}$ at 9 months elapsed and then showed increasing trend onward (Fig. 3E). Remaining $\mathrm{K}$ in decomposing $Q$. mongolica litter decreased rapidly to $28.6 \%$ of the initial $\mathrm{K}$ mass during early stage of 9 months decomposition (Fig. 3F). There was no $\mathrm{K}$ immobilization period in decomposing $Q$. mongolica litter. After 33 months elapsed, $36.8 \%$ of initial $\mathrm{K}$ mass was released. This pattern is due to the fact that $\mathrm{K}$ is not structural components of plant litter and is subject to physical removal by leaching (Gosz et al. 1973, Lousier and Parkinson 1978, Xu et al. 2004).

Initial $\mathrm{Ca}$ concentration of $Q$. mongolica litter was $3.14 \mathrm{mg} / \mathrm{g}$. Ca concentration of decomposing $Q$. mongolica litter showed a rollercoast pattern (Fig. 3G). There was net Ca mineralization after 12 months decomposition (Fig. 3H). After 33 months decomposition, about $47.3 \%$ of initial $\mathrm{Ca}$ mass in $Q$. mongolica litter was released. Gosz et al. (1973) and Edmonds and Thomas (1995) reported that Ca release pattern was somewhat similar to the weight loss pattern because it is a structural component and thus protected from physical leaching. However, Klemmedson et al. (1985) found an accumulation of $\mathrm{Ca}$ and a slow release in the later stage of decomposition.

Initial $\mathrm{Mg}$ concentration of $Q$. mongolica litter was $1.11 \mathrm{mg} / \mathrm{g}$ which was much lower than that of $Q$. variabilis (Namgung et al. 2008). In decomposing $Q$. mongolica litter, $\mathrm{Mg}$ concentration increased steadily during the experimental period (Fig. 3I). Net $\mathrm{Mg}$ mineralization was occurred in decomposing $Q$. mongolica litter during the experimental period (Fig. 3J). After 33 months elapsed, $25.6 \%$ of initial $\mathrm{Mg}$ mass in $Q$. mongolica litter was released. Gosz et al. (1973) and $\mathrm{Xu}$ et al. (2004) reported that dynamics of $\mathrm{Mg}$ are similar to the pattern of $\mathrm{K}$. In plants, $\mathrm{Mg}$ is readily extracted with water (Marshner 1995). This means that Mg could be leached out by rainwater in the decomposition process ( $\mathrm{Xu}$ et al. 2004).

\section{ACKNOWLEDGEMENTS}

This study was supported by Korea Ministry of Environment as "National Long-Term Ecological Research Project".

\section{LITERATURE CITED}

Alhamd L, Arakaki S, Hagihara A. 2004. Decomposition of leaf litter of four species in a subtropical evergreen broad-leaved forest, Okinawa Island, Japan. Forest Ecol Manag 202: 1-11.

Allen SE, Grimshaw HM, Parkinson JA, Quarmby C. 1974. Chemical Analysis of Ecological Materials. Blackwell. Oxford.

Baker TT, Lockaby BG, Conner WH, Meier CE, Stanturf JA, Burke MK. 2001. Leaf litter decomposition and nutrient dynamics in four southern forested floodplain communities. J Am Soc Soil Sci 65: 
1334-1347.

Berendse F, Bobbink R, Rouwenhorst G. 1989. A comparative study on nutrient cycling in wet heathland ecosystems. II. Litter decomposition and nutrient mineralization. Oecologia $78: 338-348$.

Moro MJ, Domingo F. 2000. Litter decomposition in four woody species in a Mediterranean climate: weight loss, $\mathrm{N}$ and $\mathrm{P}$ dynamics. Ann Bot 86: 1065-1071.

Berg B, Staaf H. 1981. Leaching accumulation and release of nitrogen in decomposing forest litter. Ecol Bull 33: 163-178.

Berg B, Staaf H, Wessen B. 1987. Decomposition and nutrient release in needle litter from nitrogen-fertilized Scats pine (Pinus sylvestris) stands. Scand J Forest Res 2: 399-415.

Dziadowiec H. 1987. The decomposition of plant litterfall in a oaklinden-hornbeam forest and an oak-pine mixed forest of the Bialoweza National Park. Acta Soc Bot Pol 56: 169-185.

Edmonds RL. Thomas TB. 1995. Decomposition and nutrient release from green needles of western hemlock and Pacific silver fir in an old-growth temperate rain forest, Olympic National Park, Washington, Can J Forest Res 25: 1049-1057.

Enriquez S, Duarte CM, Sand-Jensen K. 1993. Patterns in decomposition rates among photosynthetic organisms: The importance of C:N:P content. Oecologia 94: 457-471.

Fog K. 1988. The effect of added nitrogen on the rate of decomposition of organic matter. Biol Rev 63: 433-462.

Gosz JR, Likens GE, Bormann FH. 1973. Nutrient release from decomposing leaf and branch litter in the Hubbard Brook Forest, New Hampshire. Ecol Monogr 43: 173-191.

Janssen BH. 1996. Nitrogen mineralization in relation to C:N ratio and decomposability of organic materials. Plant and Soil 181: 39-45.

Jensen V. 1974. Decomposition of angiosperm tree leaf litter. In Biology of Plant Litter Decomposition. Vol 1 (Dickson CH, Pugh GJF, eds). Academic Press, New York. pp 69-104.

Klemmedson JO, Meier CE, Campbell RE. 1985. Needle decomposition and nutrient release in ponderosa pine ecosystems. Forest Sci 31: $647-660$.

Lousier JD, Parkinson D. 1978. Chemical element dynamics in decomposing leaf litter. Can J Bot 56: 2795-2812.

Mashner H. 1995. Mineral Nutrition of Higher Plants. 2nd edition. Aca- demic Press, London.

Meentemeyer V. 1978. Macroclimate and lignin control of litter decomposition rates. Ecology 59: 465-472.

Melillo JM, Aber JD, Muratore JF. 1982. Nitrogen and lignin control of hardwood leaf litter decomposition dynamics. Ecology 63: $621-626$

Moro MJ, Domingo F. 2000. Litter decomposition in four woody species in a Mediterranean climate: weight loss, $\mathrm{N}$ and $\mathrm{P}$ dynamics. Ann Bot 86: 1065-1071.

Namgung J, Han AR, Mun HT. 2008. Weight loss and nutrient dynamics during leaf litter decomposition of Quercus variabilis and Pinus densiflora at Mt. Worak National Park. J Ecol Field Biol 31: $291-295$.

Olson JS. 1963. Energy storage and the balance of producers and decomposers in ecological systems. Ecology 44: 321-331.

Satchell JE. 1974. Litter - interface of animate/inanimate matter. In Biology of Plant Litter Decomposition. Vol. 1 (Dickinson CH, Pugh GJF, eds). Academic Press, New York. pp. xiii-xliv.

Schlesinger WH. 1985. Decomposition of chaparral shrub foliage. Ecology 66: 1353-1359.

Seereeram S, Lavender P. 2003. Analysis of leaf litter to establish its suitability for compositing to produce a commercially saleable product. A Report Prepared for SWAP. Aquat Environ p. 18.

Swift MJ, Heal OW, Anderson JM. 1979. Decomposition in Terrestrial Ecosystems. Studies in Ecology, vol. 5. University of California Press, Berkeley, CA.

Taylor BR, Parkinson D, Parsons WFJ, 1989. Nitrogen and lignin content as predictor of litter decay rates: A microcosm test. Ecology 70: 97-104.

Wieder RK, Lang GE. 1982. A critique of the analytical methods used in examining decomposition data abtained from litter bags. Ecology 63: $1636-1642$.

Xu X, Hirata E, Enoki T, Tokashiki Y. 2004. Leaf litter decomposition and nutrient dynamics in a subtropical forest after typhoon dis* turbance. Plant Ecol 173: 161-170.

(Received May 4, 2009; Accepted May 18, 2009) 